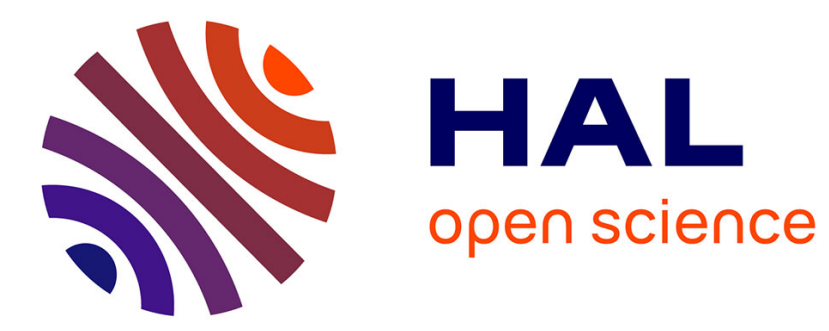

\title{
An inventory of finds of potin coins from west and southwest Germany \\ David Wigg
}

\section{To cite this version:}

David Wigg. An inventory of finds of potin coins from west and southwest Germany. Gallia Archéologie de la France antique, 1995, Les potins gaulois, 52, pp.101-116. 10.3406/galia.1995.3132 . hal-01911227

\section{HAL Id: hal-01911227 \\ https://hal.science/hal-01911227}

Submitted on 27 Feb 2020

HAL is a multi-disciplinary open access archive for the deposit and dissemination of scientific research documents, whether they are published or not. The documents may come from teaching and research institutions in France or abroad, or from public or private research centers.
L'archive ouverte pluridisciplinaire HAL, est destinée au dépôt et à la diffusion de documents scientifiques de niveau recherche, publiés ou non, émanant des établissements d'enseignement et de recherche français ou étrangers, des laboratoires publics ou privés.

\section{(ㅇ)(1) $\$$}

Distributed under a Creative Commons Attribution - NonCommercial - NoDerivatives $\mid 4.0$ 


\title{
4.4. An Inventory of Finds of Potin Coins from West and Southwest Germany
}

\author{
David G. Wigg
}

\begin{abstract}
Résumé. Cette analyse de la répartition des monnaies de potin en Allemagne du Sud-Ouest et de l'Ouest est fondée sur un inventaire des pièces trouvées dans cette région. Les potins se trouvent surtout dans les oppida et la distribution des monnaies s'accorde à peu près avec celle des oppida : sur la rive gauche du Rhin au sud-est de l'Eifel, sur la rive droite en Hesse centrale et méridionale, et en BadeWurtemberg. Les émissions les plus importantes sont celles, dites des Sequani, "à la grosse tête " (sur la rive droite du Rhin) et celles des Leuci et des Remi (surtout en Hesse et sur la rive gauche du Rhin). On n'a pas trouvé de traces de production de potins dans la région étudiée, mais il est possible que les Treveri en aient produit dans un de leurs oppida en Allemagne du Sud-Ouest. Contrairement aux émissions des Sequani, Leuci et Remi, les potins des Treveri ne se trouvent pas sur la rive droite du Rhin. On ne peut pas encore délerminer si ce phénomène résulte de la chronologie, ou si les pièces des Treveri ont pu circuler régionalement dans un espace moins étendu.
\end{abstract}

\begin{abstract}
Zusammenfassung. Ausgehend von einem Inventar von Funden von Potin-Münzen in West- und Südwestdeutschland wird das Vorkommen von Potin in diesem Gebiel untersucht. Potin wird vor allem in den Oppida gefunden und seine Verbreitung deckt sich in etwa mit der der Oppida : im linksrheinischen Gebiet südöstlich der Eifel, im rechtsrheinischen vor allem in Mittel- und Südhessen sowie im südlichen Baden-Württemberg. Die wichtigsten "Prägungen" sind die Sequani “à la grosse tête" (hauplsächlich rechtsrheinisch) und die I.euci und Remi (vor allem linksrheinisch sowie in Hessen). Es gibt keine konkreten Hinweise für eine Potinproduktion im Untersuchungsraum, obwohl eventuell in einem der treverischen Oppida in Südwestdeutschland damit zu rechnen ist. Im Gegensatz zu den oben erwähnten Potingruppen beschränken sich die treverischen Potins auf das linksrheinische Gebiet. Allerdings ist noch nicht klar, ob dafür chronologische Faktoren verantwortlich sind, oder aber die Potins der Treverer einen eingeschränkten und nur regionalen Umlauf erführen.
\end{abstract}

Since Simone Scheers' work on the coinage of Belgic Gaul (Scheers, 1977), potin from Germany has received little attention. Work has been restricted to surveys of coins from individual sites and areas, which have included potin more or less incedently ${ }^{86}$, or has been a by-product of studies of coinage from neighbouring areas, above all Luxembourg ${ }^{87}$.

The aim of this paper is to provide a survey of finds of Celtic potin coins from West and Southwest Germany as a basis for further study, as well as drawing a few preliminary conclusions from the material presented. It is based upon a computer database of finds of Celtic coins established by Fundmünzen der Antike, Frankfurt ${ }^{88}$.

86. V. Zedelius (1984), K.J. Gilles (1984). More recently, Gilles (1992, 1993) has produced a catalogue of Celtic coins from the area around Trier. For Baden-Württemberg : D. Mannsperger (1984).

87. L. Reding (1972) ; R. Weiller (1984), S. Scheers (1979).

88. The area covered by the database includes the Federal States (Bundesländer) : Baden-Württemberg, Rheinland-Pfalz, Saarland, Hessen, Nordrhein-Westfalen and Niedersachsen (fig. 53). No potin is recorded from Schleswig-Holstein.

The database primarily relies upon published sources, but includes unpublished supplementary material from the Fundmünzen der Antike Archivcs in Frankfurt, as wcll as from muscums. My thanks arc above all
Most of the material comes from old excavations, frequently with poorly recorded archaeological contexts, and has often not survived the vagaries of the Second World War, making a post mortem of individual coins impossible. The majority of more recent discoveries have fared little better, being made by "hobby archaeologists" using metal detectors, who rarely report their finds and have completely stripped several important find-spots, without the possibility of a satisfactory record being kept. In those cases where cooperative finders have supported the work of official archaeologists, our knowledge, above all of the distribution of potin, has indeed been increased, but such finds have no archaeological context, and

due to the late $\mathrm{V}$. Zedelius, Rheinisches Landesmuseum, Bonn, J. Schulze-Forster, Marburg and K.J. Gilles, Rheinisches Landesmuseum, Trier, who kindly gave me access to the manuscript of his article "Keltische Fundmünzen im Östlichen Treverergebiet" prior to publication. H. Schubert, Frankfurt, provided photos of the Heidetränk/Goldgrube material. Information from Rheinhessen was provided by J. Gorecki, Frankfurt, and G. Rupprecht, Mainz. I am also indebted to Wolfgang Schmidt, Frankfurt, who entered most of the material onto the database.

The author would be grateful for any further information on finds of Celtic coins from the area. 


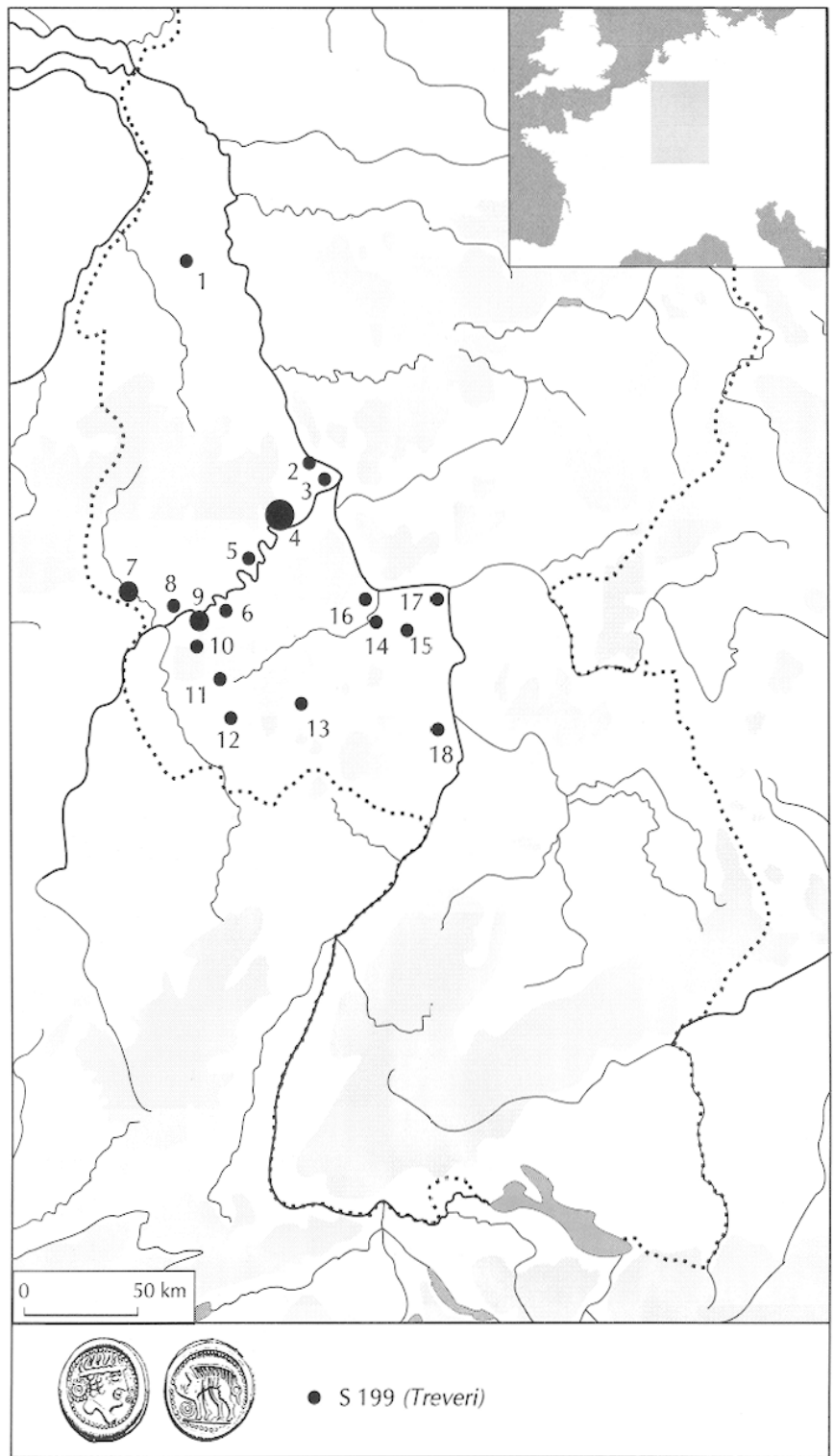

Fig. 43. Scheers 199.

cannot answer questions of chronology. The latter aspect is further hampered by the lack of large-scale excavations in recent years in oppida, such as have been conducted at the Titelberg, in Luxembourg, which might provide welldated contexts for potin.

\section{DISTRIBUTION : “LOCAL” TYPES}

\section{Treverian types (fig. 43-45)}

The only Celtic tribe from the region studied of whom we can with confidence say that they produced potin are the

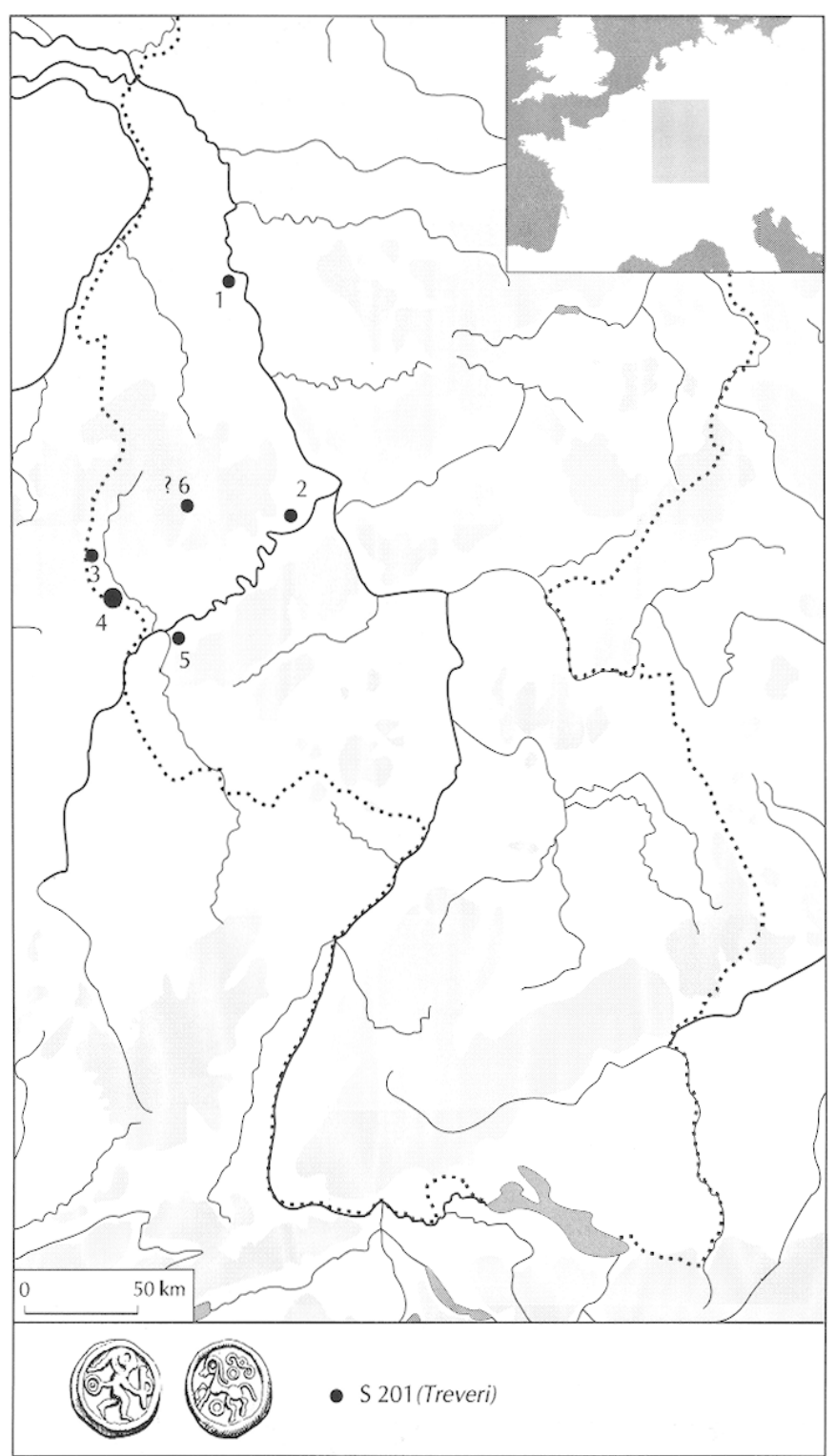

Fig. 44. Scheers 201.

Treveri. Their territory covered the hills to the left and right of the Moselle (Hunsrück and Eifel), and extended southwestwards beyond the German border through to Luxembourg, Belgium and France.

Three potin types have been attributed by Scheers to the Treveri, her nos. 199, 200 and 201. The mints for these three types cannot be localised, although Reding limits the possibilities to the Titelberg and the Martberg ${ }^{89}$ (tabl. 12).

S 199 and 200 are the commonest types in the study

89. Reding (1972). See below for the proportions of S 199-201 at main Treverian sites. 


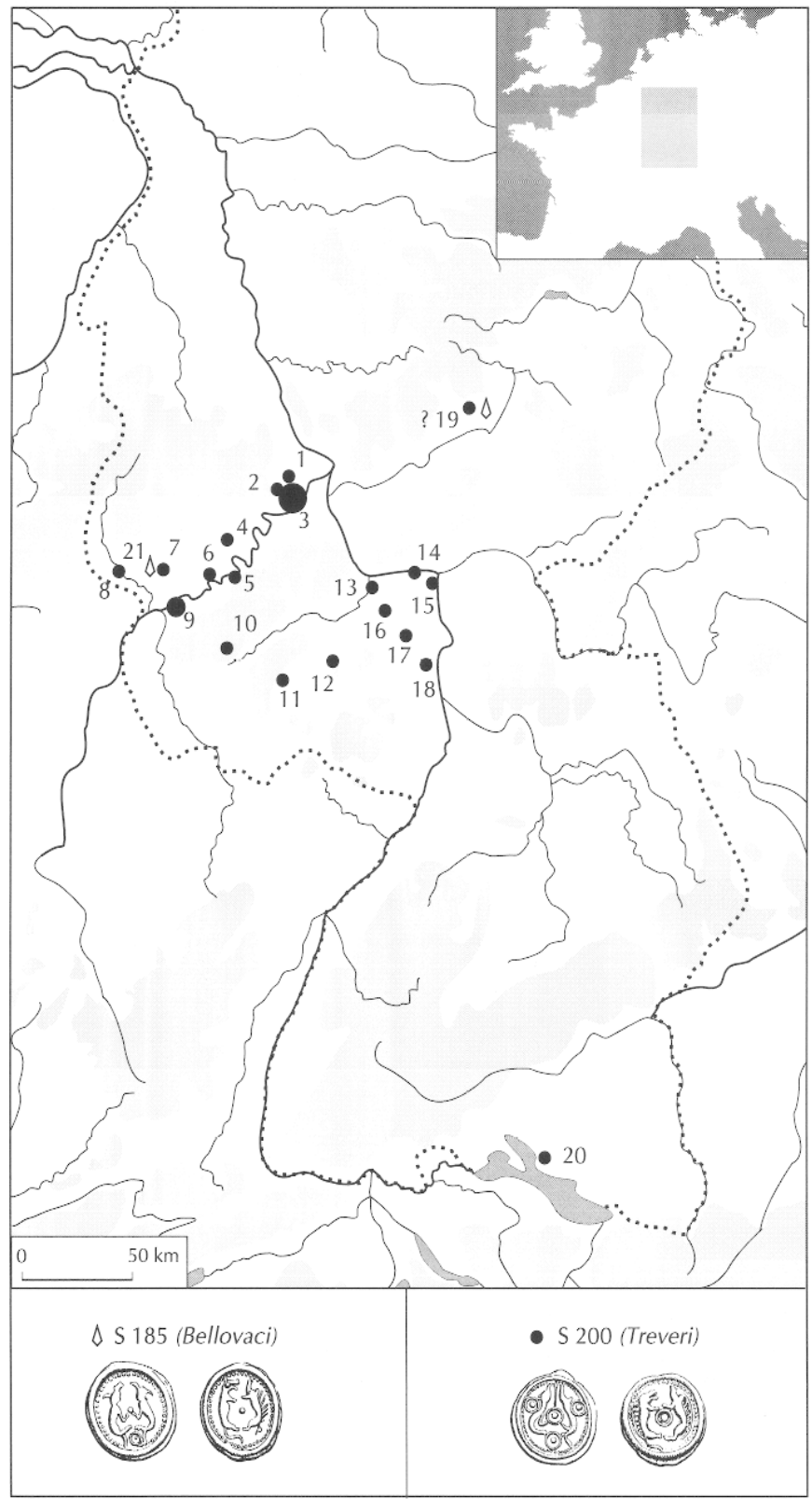

Fig. 45. Scheers 185 et Scheers 200.

area, and the new material presented here confirms the distribution mapped by Scheers. With the exception of one piece from Mühlhofen, near Lake Constance (fig. 45 no. 20), and a possible $S 200$ from the Dünsberg, in Hessen (fig. 45, no. 19), both types are restricted to the left bank of the Middle Rhine, and the Moselle valley. The main concentrations are at the oppida of Wallendorf and Martberg, as well as at Trier.

The distribution of S 201 is more restricted, being limited to the Moselle valley and the area to the Northwest. The Eastern region towards the Middle
Tabl. 12. S 199-201 (Treverian types) expressed as a percentage of all identifiable potin from individual areas.

\begin{tabular}{|l|c|}
\hline Rheinland-Pfalz/Saarland & $37 \%$ \\
\hline Koblenz district & $(80 \%)$ \\
\hline Trier district & $(31 \%)$ \\
\hline Saarland & $(29 \%)$ \\
\hline Rheinhessen & $(33 \%)$ \\
\hline Pfalz & $(6 \%)$ \\
\hline Hessen & \\
\hline Baden-Württemberg & $1 \%$ \\
\hline
\end{tabular}

Tabl. 13. Numbers of $S 199-201$ at the main Treverian sites. The figures for the Titelberg are taken from Reding (1972). For $S 200$ the figure for Reding's classe 7 alone is given in brackets.

\begin{tabular}{|c|c|c|c|c|}
\cline { 2 - 5 } \multicolumn{1}{c|}{} & Martberg & Wallendorf & Trier & Titelberg \\
\hline S 199 & 33 & 5 & 4 & 124 \\
\hline S 200 & 21 & 2 & 7 & $60(49)$ \\
\hline S 201 & 2 & 4 & - & 74 \\
\hline
\end{tabular}

Rhine, so prominent for S 199 and 200, has produced no examples, nor is it found in significant numbers at Trier or at the Martberg, where the other Treverian types are common (tabl. 13).

The question of Martberg or Titelberg as production centre for S 199 and 200 must remain open, but if S 201 is indeed of Treverian origin, then the Titelberg is the most likely site for the mint.

\section{DISTRIBUTION : "IMPORTED" TYPES}

There are three main imported potin types found in the area.

\section{S 186. Leuci (fig. 46-47)}

This is the most numerous individual potin type in Germany, with 148 examples from the study area. The distribution is similar to that noted for S 199 and 200, but with significant extensions to the East : on the left bank of the Rhine in the Pfalz (fig. 46, nos. 34-44), on the right bank of the Upper Rhine in Baden-Württemberg (fig. 46, nos. 45-50), and in Hessen to the North of the Main (fig. 46, nos. 26-29), where it is easily the most frequent potin type (tabl. 14). 


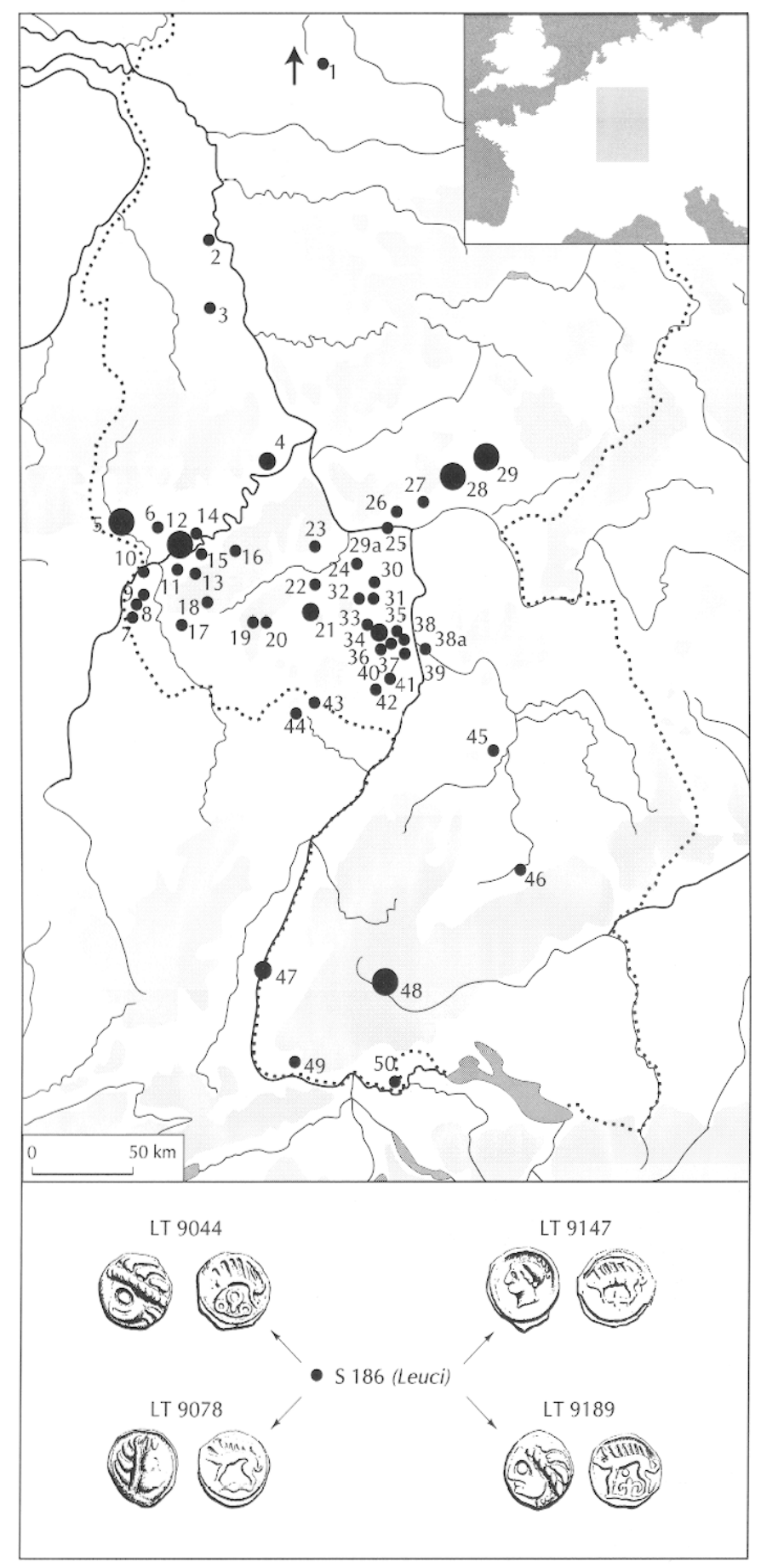

Where it was possible to determine the symbol beneath the boar on the reverse, the lily (Scheers classe $\mathrm{Ij}$ ) is the most widespread, being found throughout the area on both sides of the Rhine (fig. 47). In Baden-Württemberg in the South, as well as in Hessen (Goldgrube/Heidetränk, no. 28) we also find significant numbers of Scheers classe
Fig. 46. Scheers 186.

Fig. 47. Scheers 186 (according to Scheers classes).

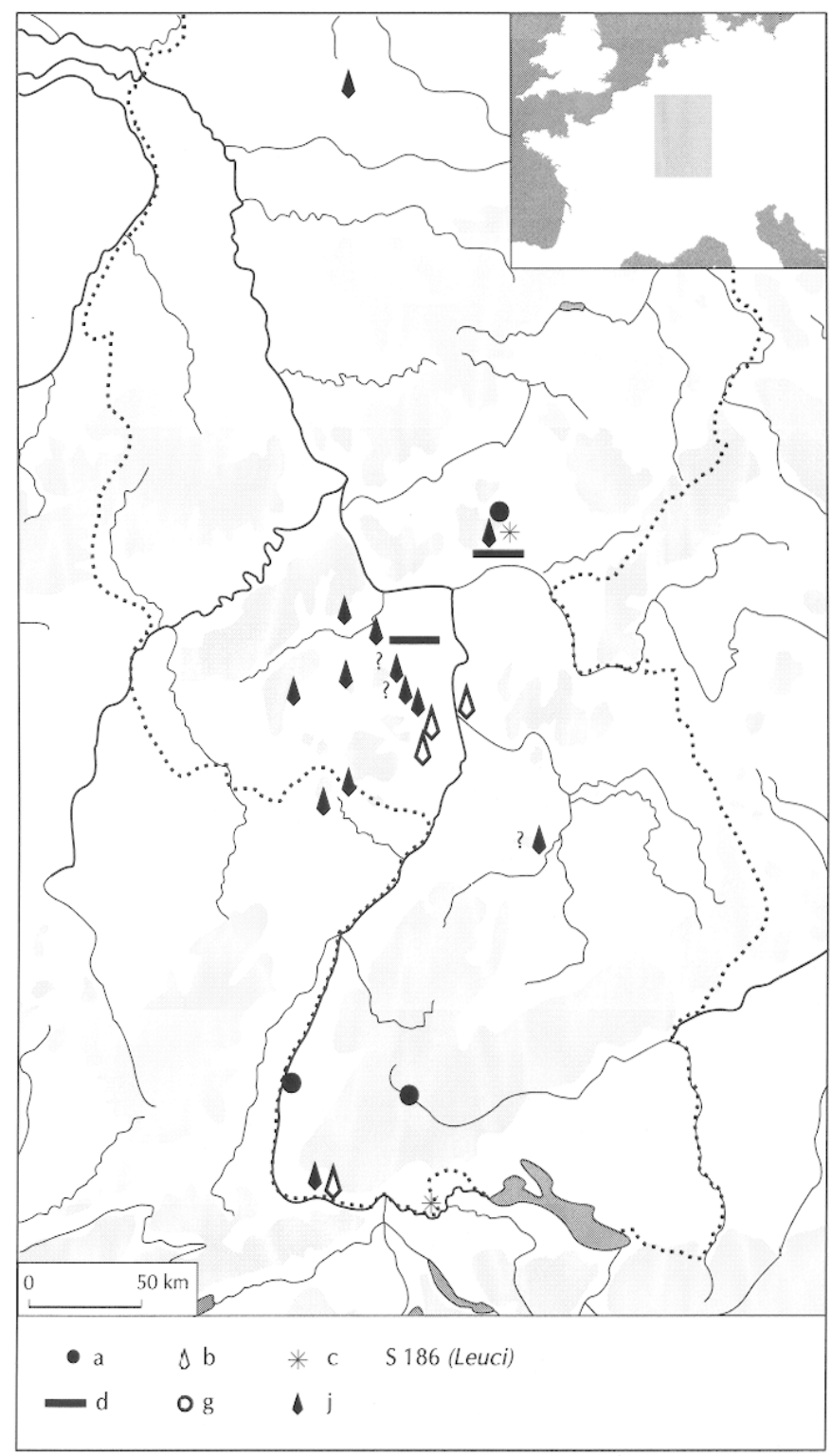

Ia. The oppidum of Goldgrube/Heidetränk has also produced four examples of Scheers classe Id, otherwise recorded only at Uffhafen (no. 29a). In the area around the confluence of the Rhine and Neckar there seems to be a small concentration of Ib (Mutterstadt, no. 37; Neustadt, no. 40 ; Ladenburg, no. 38a). 
Tabl. 14. S 186 expressed as a percentage of all identifiable potin from individual areas.

\begin{tabular}{|l|c|}
\hline Rheinland-Pfalz/Saarland & $29 \%$ \\
\hline Koblenz district & $(9 \%)$ \\
\hline Trier district & $(35 \%)$ \\
\hline Saarland & $(21 \%)$ \\
\hline Rheinhessen & $(23 \%)$ \\
\hline Pfalz & $(54 \%)$ \\
\hline Hessen & $67 \%$ \\
\hline Baden-Württemberg & $21 \%$ \\
\hline
\end{tabular}

Tabl. 15. S 191 expressed as a percentage of all identifiable potin from inditidual areas.

\begin{tabular}{|l|c|}
\hline Rheinland-Pfalz/Saarland & $19 \%$ \\
\hline Lower Moselle & $(5 \%)$ \\
\hline Trier region & $(22 \%)$ \\
\hline Saarland & $(14 \%)$ \\
\hline Rheinhessen & $(33 \%)$ \\
\hline Pfalz & $(29 \%)$ \\
\hline Hessen & $6 \%$ \\
\hline Baden-Württemberg & $2 \%$ \\
\hline
\end{tabular}

Tabl. 16. Sequani potins expressed as a percentage of all identifiable potin from individual areas.

\begin{tabular}{|l|c|}
\hline Rheinland-Pfalz/Saarland & $2 \%$ \\
\hline Hessen & $22 \%$ \\
\hline Baden-Württemberg & $69 \%$ \\
\hline
\end{tabular}

\section{S 191. Remi (fig. 48)}

The distribution of the "personnage courant" type attributed to the Remi lies between that of the Treverian and Leucic potins (tabl. 15).

Here too the main area of circulation is to the left of the Rhine, with a notable concentration in the East of the region, that is in Rheinhessen and the Pfalz. Although, unlike their Treverian counterparts, the Remic potins did cross the Rhine, it was only in small numbers.

Isolated examples of two further Remi types, S 194 \& 195 are also recorded (fig. 50).

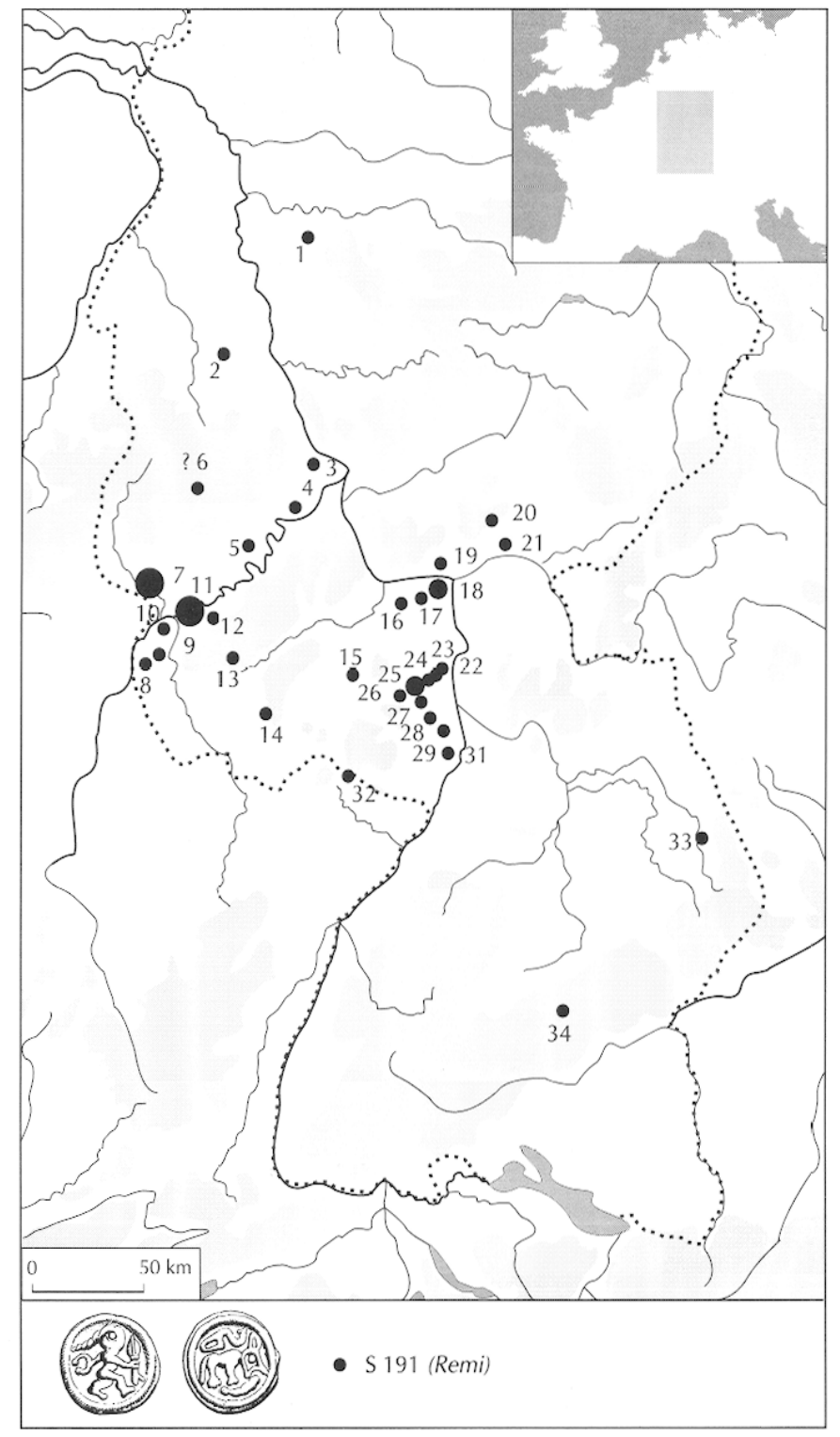

Fig. 48. Scheers 191 .

Sequani (fig. 49)

The distribution of the potins "à la tête diabolique" of the Sequani is very different (tabl. 16).

They are mainly found in the Black Forest region of Baden-Württemberg, where they account for almost three-quarters of all potins. They are also important in Hessen, but the isolated examples from the left bank of the Rhine are statistically insignificant. There is new evidence that Sequani potins were also produced in BadenWürttemberg (Burkhardt, 1993) 


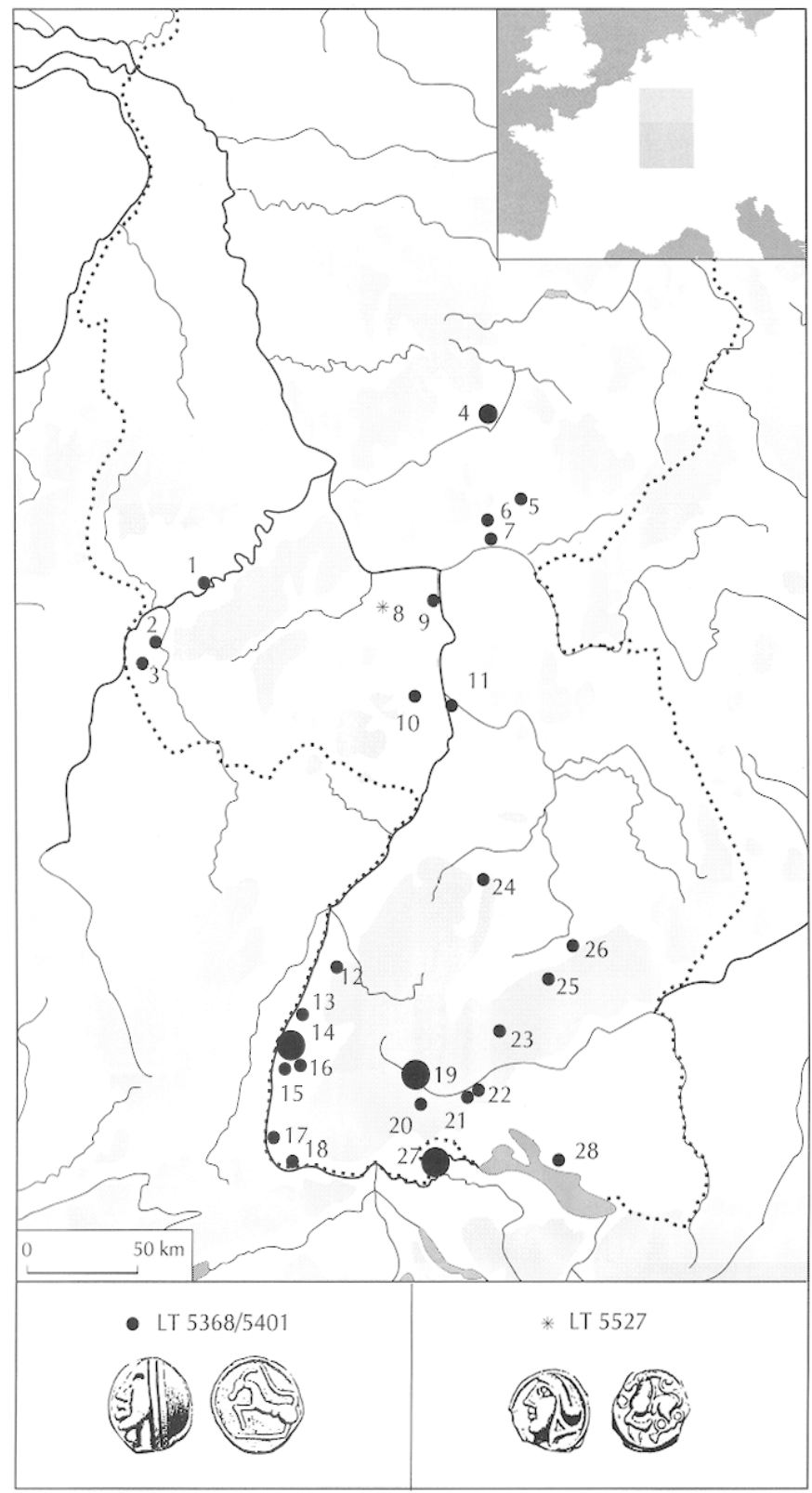

Fig. 49. La Tour 5368/5401, La Tour 5527.

Fig. 50. Scheers 190, 194, 195, 197 and 198.

\section{Additional types}

Other potin types from the Bellovaci (fig. 45), Nervii (fig. 50), Suessiones (fig. 50), Senones (fig. 51), Aedui, Helvetii, "incertaines de l'Est" and Lingones (fig. 52), are present in only small numbers. They are found in the same areas as the main potin coinages discussed above.

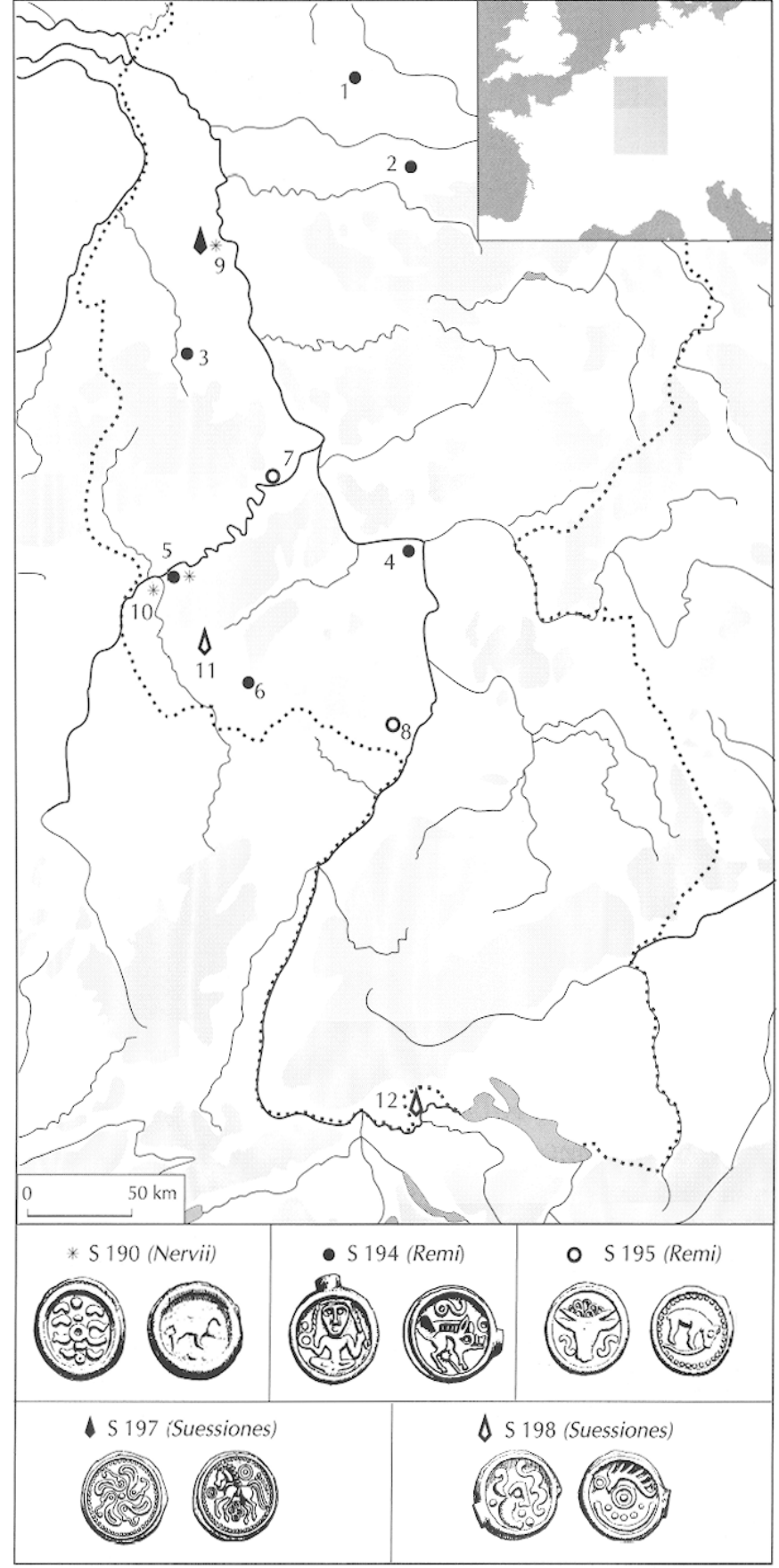

\section{DISTRIBUTION : CONCLUSIONS}

Potin coins occur almost exclusively in a closely definable area of West and Southwest Germany : to the West of the Rhine they are restricted to Rheinland-Pfalz and Saarland, rarely being found on the Lower Rhine in NordrheinWestfalen, where late Celtic coinage (Germanus Indutilli L, 


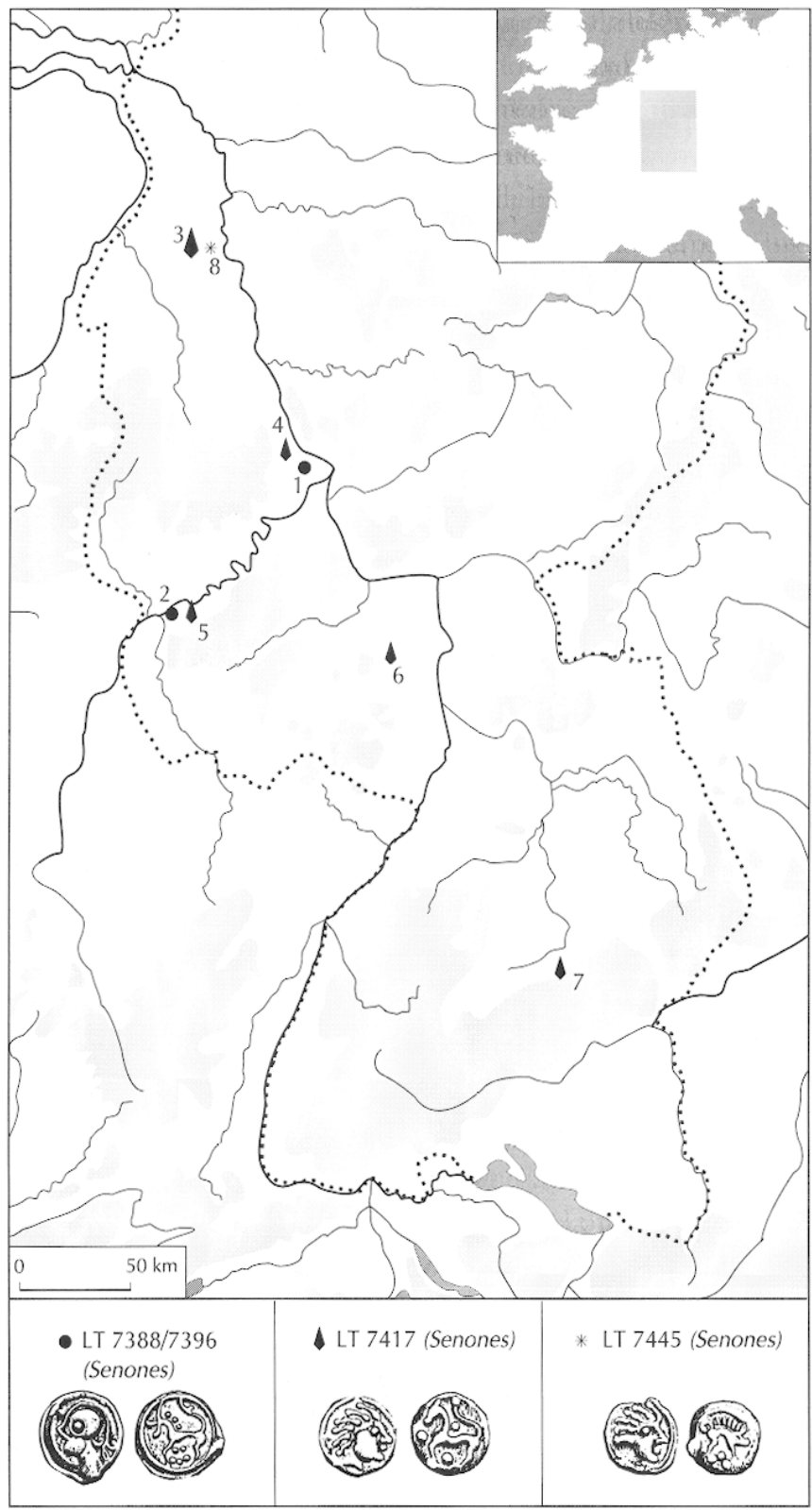

"Aduatuce" and Bochum-type rainbow cups) is present in large numbers. To the East of the Rhine, central Hessen marks the northern limit of their distribution. There is a gap in southern Hessen and northern BadenWürttemberg, where Celtic silver and gold coinage is otherwise common (Mannsperger, 1984, p. 251-252), before we find another concentration of potin finds in the Black Forest area of southern Baden-Württemberg.

Their distribution is clearly based on oppida. The northern extension of their occurrence coincides closely with the limit of the oppida culture, and the largest individual concentrations are generally oppida (Martberg : 67,
Fig. 51. La Tour 7388/7396, La Tour 7417, La Tour 7445.

Fig. 52. Aedui, Lingones, "incertaines de l'Est ", Helvetii.

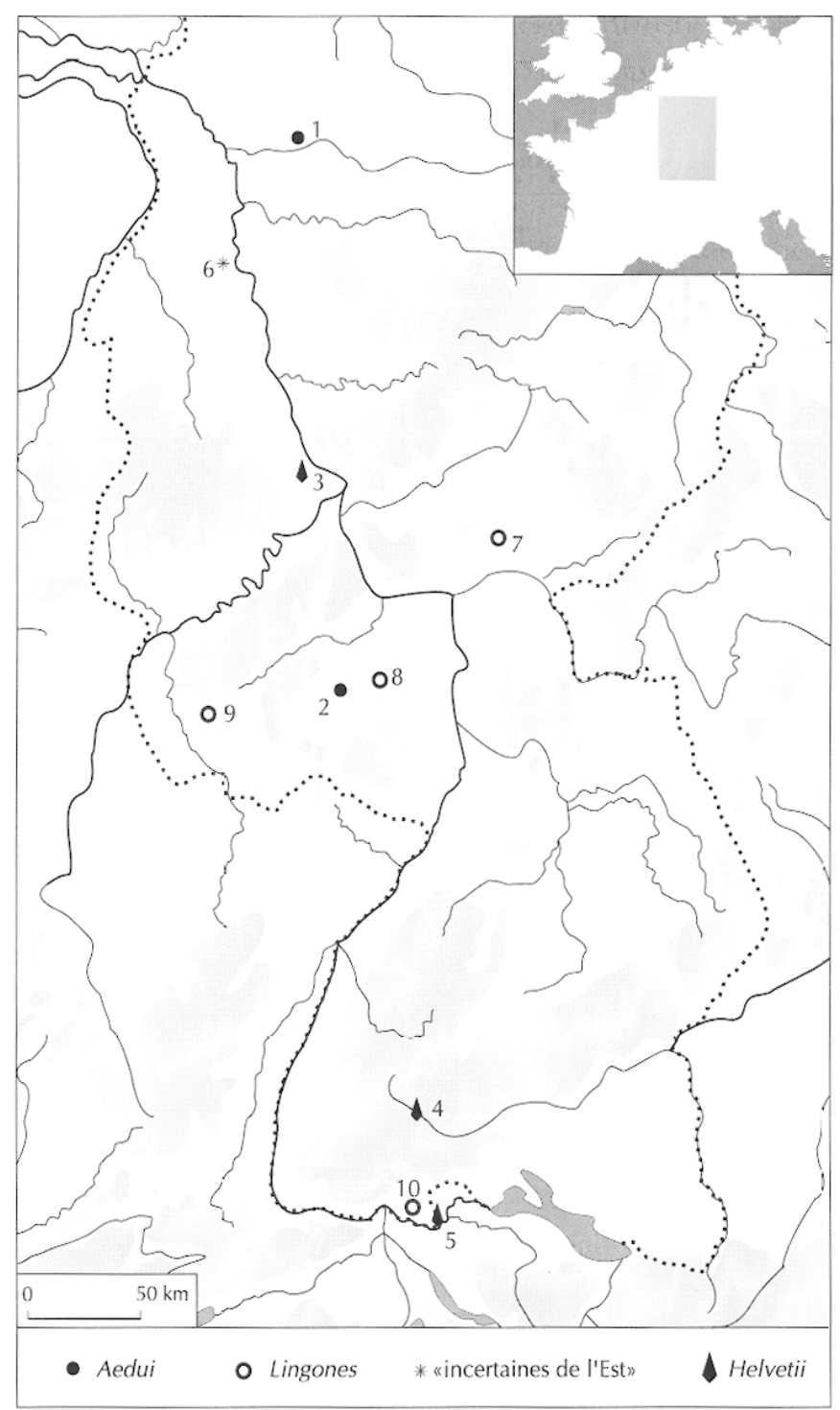

Wallendorf : 46, Hüfingen : 31, Goldgrube/Heidetränk : 28, Breisach-Hochstetten : 21, Altenburg : 17 coins). However, caution is necessary, as this may be due to the pattern of research, with oppida receiving more attention and so producing larger numbers of coin finds. Trier (28 coins) is the exception, but K.J. Gilles postulates a preRoman settlement here (Gilles, 1992).

\section{Chronology}

Little new evidence can be provided here on the chronology of potin. Of the three main importcd types, C.C. 


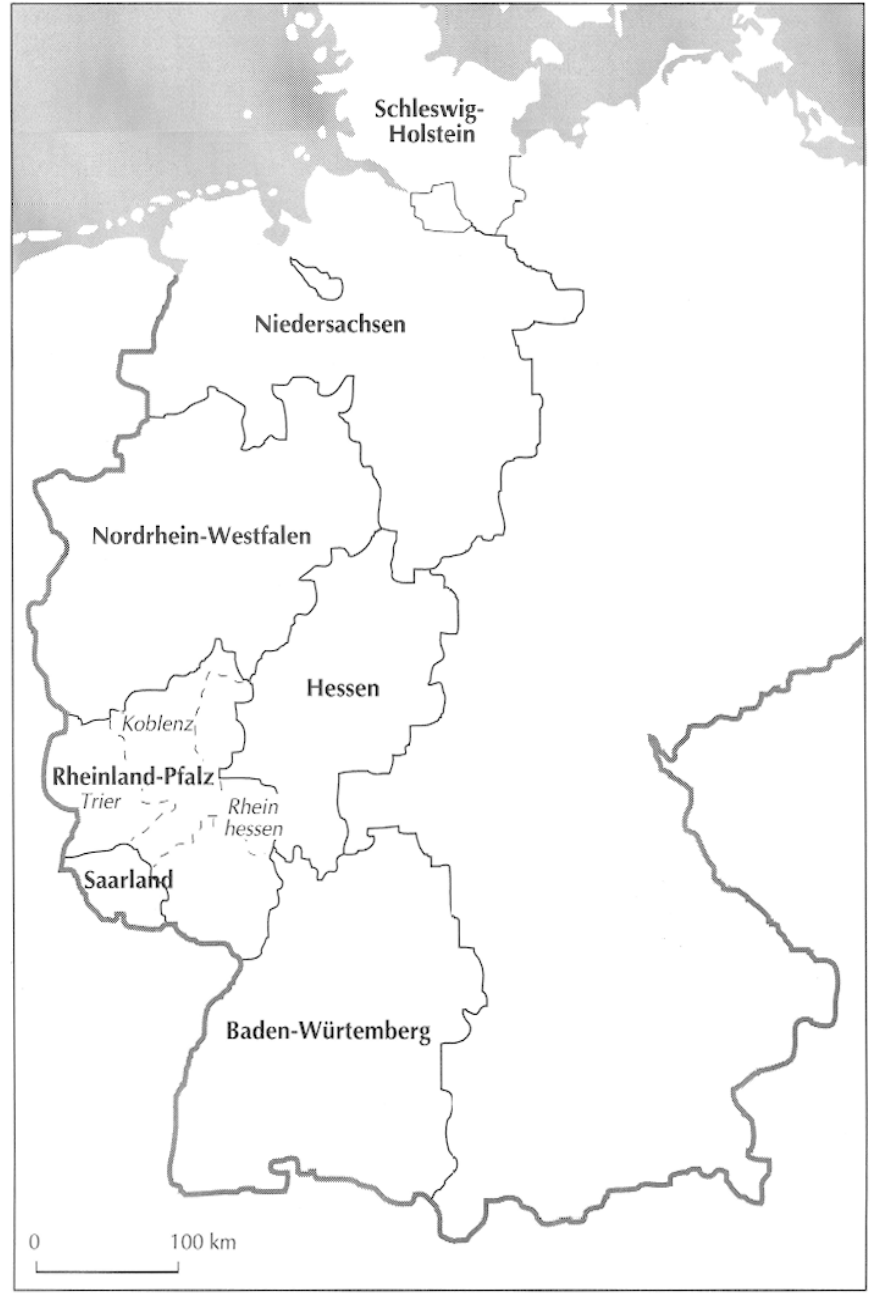

Fig. 53. Les états fédéraux (Bundesländer) de l'ouest et du sud-ouest de l'Allemagne. Pour le Rheinland-Pfalz, les districts (Regierungsbezirke) sont aussi indiqués.

Haselgrove has recently demonstrated that $\mathrm{S} 191$ dates to the La Tène D1 period, although it continued to circulate in D2 (Haselgrove, 1993). The Sequani potins are now also generally accepted as commencing in D1 (FurgerGunti, von Kaenel, 1976), and the same can be said of S 186, attributed to the Leuci ${ }^{90}$. Two La Tène D1 burials from Germany have produced Leucic potins : Wederath, grave 1311 (Cordie-Hackenberg, Haffner, 1991, p. 10-11) and Uffhofen (Polenz, 1982, p. 87, ${ }^{\circ} 18$ and p. 94, n ${ }^{\circ} 22$ ).

The dating of the Treverian types remains unclear, and the terminus ante quem of 30 B.C. provided by the coins in excavations at the Titelberg for S 199 and 200 is still the only fixed chronological point ${ }^{91}$. The prototype

90. Cf. Furger-Gunti, von Kaenel, 1976. H.-J. Kellner (1990, p. 37) dates S 186 somewhat earlier still, to La Tène C2/D1.
Tabl. 17. Potin as a percentage of all Celtic coins (excluding hoards) from individual areas.

\begin{tabular}{|l|c|}
\hline Nordrhein-Westfalen & $1 \%$ \\
\hline Rheinland-Pfalz/Saarland & $22 \%$ \\
\hline Hessen & $40 \%$ \\
\hline Baden-Württemberg & $22 \%$ \\
\hline
\end{tabular}

for $S 200$, the Bellovacian $S 185$, is recorded from the "fosse" at Alesia, and so predates 52 B.C. (Colbert de Beaulieu, 1955, p. 73, $n^{\circ} 173$ ). Possibly S 199 is the latest of the three Treverian types, for a late-La Tène ditch filling from the Titelberg contained seven examples, but none of S 200 and 201, although the latter are otherwise common on the site ${ }^{92}$. It is, therefore, a matter of speculation whether the Treverian potins belong to $\mathrm{D} 1$ together with the imported types. Nor can it be established whether the geographically reduced distribution of Treverian potin compared to the Leucic and Remic coins is due to chronological factors, or because Treverian coinage, while being produced at the same time as the other types, circulated less widely.

Potin is present in only very small numbers at the Augustan camps on the Rhine, and seems to have almost disappeared from circulation by 10 B.C., at least in military contexts ${ }^{93}$.

\section{Hoards}

Until recently no hoards of potin were recorded from the study area. All of the coins dealt with here are either single/stray finds or from burials (mainly of the migration period!). However, from 1989 a complex of some 250 Celtic silver and potin coins, presumably from a scattered hoard, has been discovered at Limburgerhof, near Ludwigshafen, in the Pfalz (Bernhard, Lenz-Bernhard, 1991, p. 71). The find contains Kaletedou quinarii and potins of the Leuci, Senones and Sequani, thus providing a close parallel to the Houssen hoard, near Colmar, some $170 \mathrm{~km}$ to the South (Allen, 1976).

David G. Wigg

91. Reding, 1972, p. 231-234 and p. 281-282.

92. Reding, 1972. See above for the proportions of S 199-201 at the Titelberg.

93. At Neuss there are only eight potin coins among the 2,469 Augustan or earlier stray finds (Chantraine, 1982). At Asberg the figure is $0: 712$ (Gorecki, 1981), and at Haltcrn $1: 2672$ (FMRD, V, 4058). 


\section{APPENDIX 2 (ANNEXE 2) : LISTS TO FIG. 43 TO 52}

\section{Scheers 199 (Treveri) (fig. 43)}

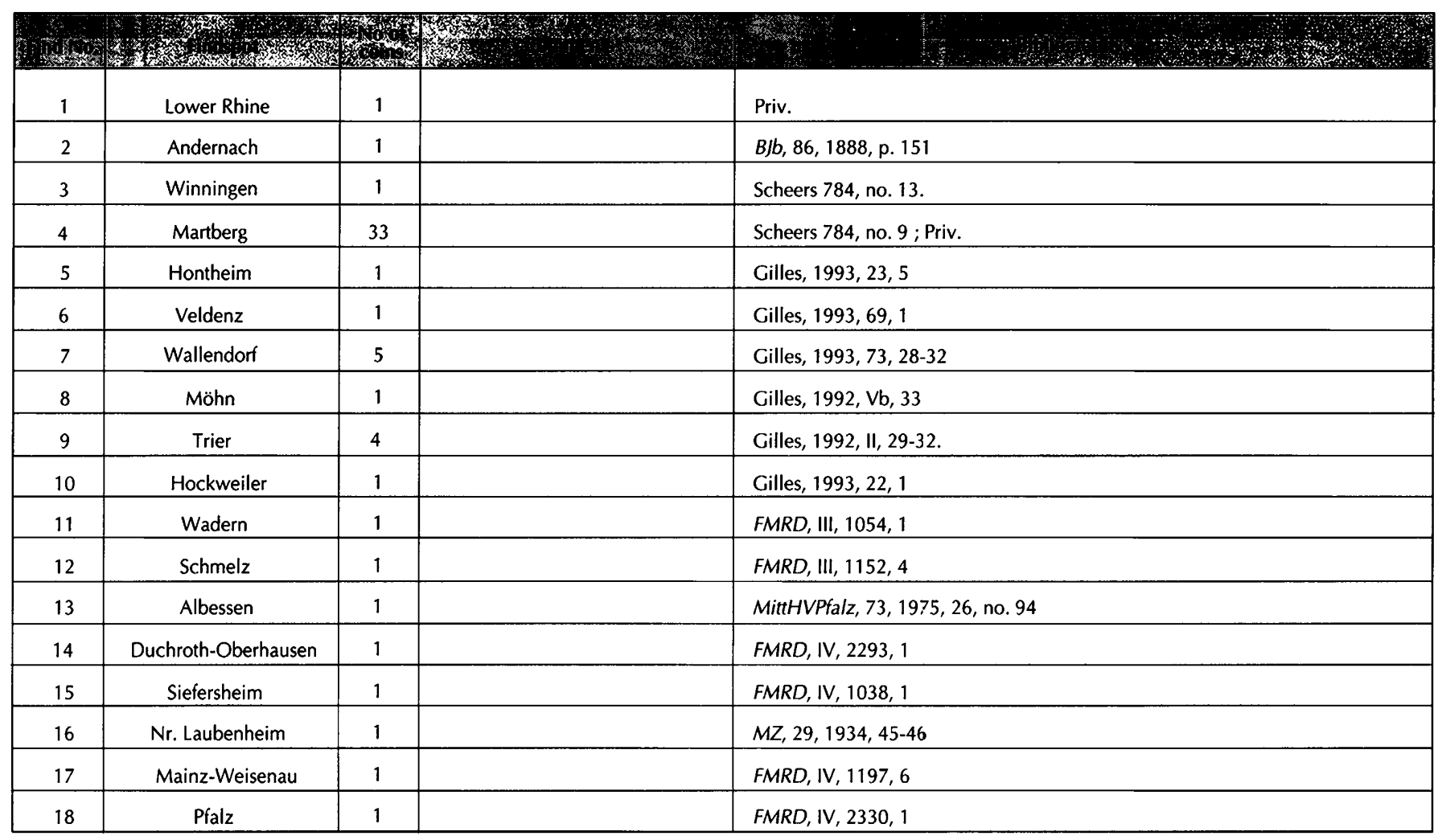

\section{Scheers 201 (Treveri - see also Scheers 191) (fig. 44)}

\begin{tabular}{|c|c|c|c|c|}
\hline 1 & Neuss & 1 & & Scheers 788, no. 8 ( $=$ Scheers 761 no. 133 , citing Behrens 348 , where in error Forr. 7 ). \\
\hline 2 & Martberg & 2 & & Scheers 788, no. 7 ; priv. \\
\hline 3 & Dahnen & 1 & & Gilles, 1993, 9, 1 \\
\hline 4 & Wallendorf & 4 & & Gilles, $1993,73,35-38$ \\
\hline 5 & Krettnach & 1 & & Gilles, 1993, 31, 1 \\
\hline 6 & Daun & 1 & S191/201 & Gilles, $1993,10,1$ \\
\hline
\end{tabular}


Scheers 200 (Treveri - see also Scheers 185) (titg. 45)

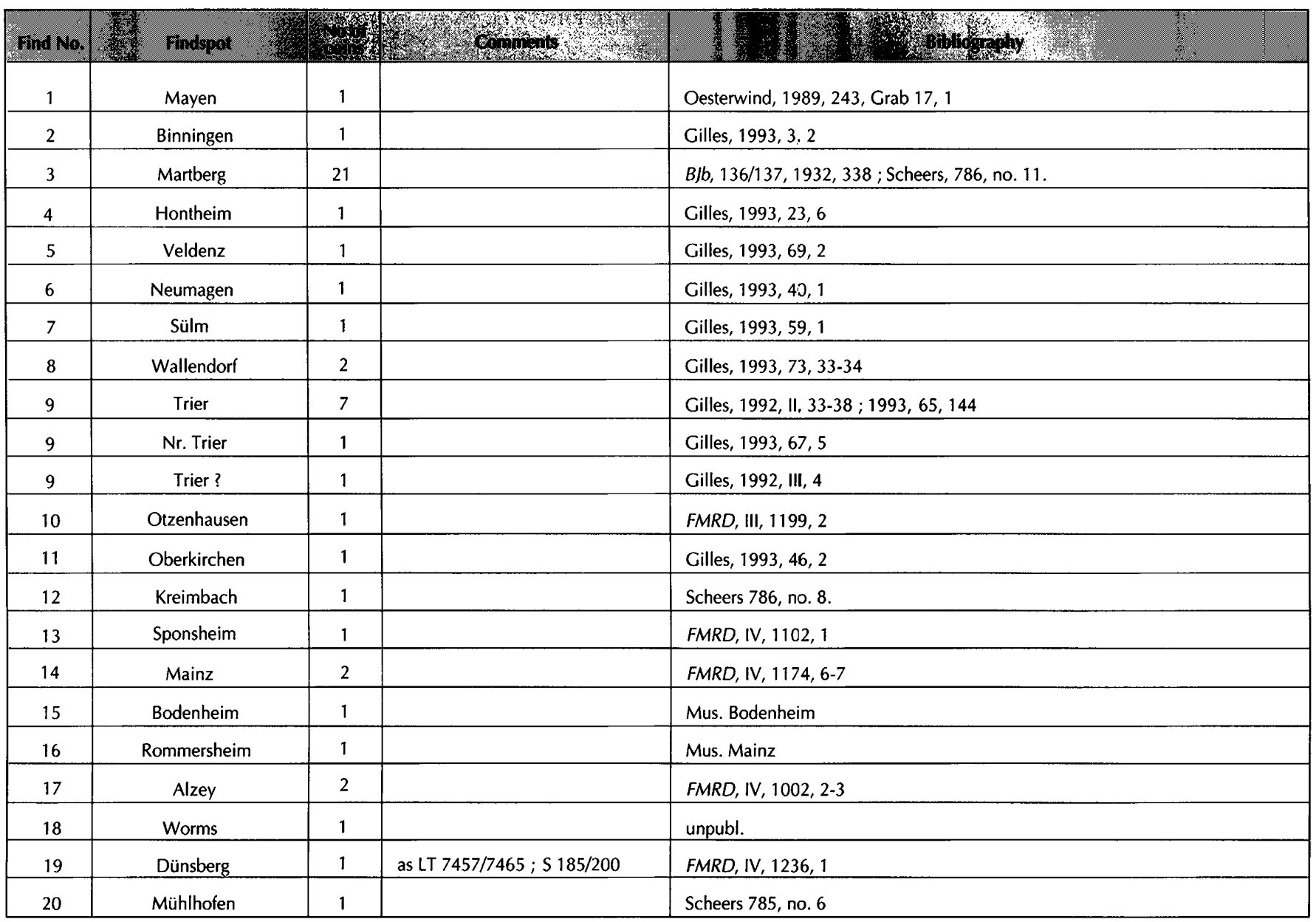

Schecrs 185 (Bellovaci - sec also Schecrs 200) (fig. 45)

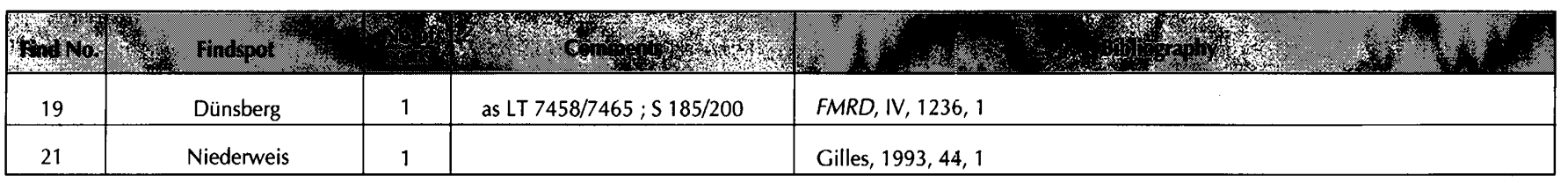




\begin{tabular}{|c|c|c|c|c|}
\hline$\frac{1}{10}$ & 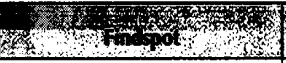 & (1) & W & (n) \\
\hline 1 & Fallingbostel & 2 & 1 uncertain, 1 Scheers classe lj & FMRD, VII, 5005, 1-2 \\
\hline 2 & Neuss & 1 & & Chantraine, 1982, 481 \\
\hline 3 & Lower Rhine & 2 & & Priv. \\
\hline 4 & Martberg & 6 & $1 \mathrm{lg}$ & Priv. \\
\hline 5 & Wallendorf & 17 & & Gilles, 1993, 73, 41-57 \\
\hline 6 & Möhn & 1 & & Gilles, 1992, Vb, 58 \\
\hline 7 & Kirf & 2 & & Gilles, 1993, 29, 3-4 \\
\hline 8 & Borg (Perl-) & 1 & & Gilles, $1993,6,6$ \\
\hline 9 & Kastel-Staadt & 2 & & Gilles, 1993, 25, 14-15 \\
\hline 10 & Tawern & 1 & & Gilles, 1993, 60a, 1 \\
\hline 11 & Waldrach & 1 & & Gilles, $1993,72,2$ \\
\hline 12 & Trier & 7 & & Gilles, $1993,65,153 ; 1993,11,111-116$ \\
\hline 13 & Trier region & 3 & & Gilles, 1993, 66, 2-4 \\
\hline 14 & Neumagen & 1 & & Gilles, $1993,40,3$ \\
\hline 15 & Büdlich & 1 & & Gilles, $1993,7,2$ \\
\hline 16 & Wederath-Belginum & 1 & & Gilles, $1992, V_{C} 2,8$ \\
\hline 17 & Mehren & 1 & & Gilles, $1993,34,1$ \\
\hline 18 & Otzenhausen & 1 & & Gilles, $1993,49,4$ \\
\hline 19 & Oberkirchen (Freisen-) & 1 & & Gilles, 1993, 46, 3 \\
\hline 20 & Albessen & 1 & I (j ?) & MittHVPfalz, 73, 1976, 26 no. 94 \\
\hline 21 & Kreimbach & 5 & $1 \mathrm{lj}$ & FMRD, IV , 2148, 2 ; Westricher Heimatbl, 8, 1977, 20 ; unpubl. \\
\hline 22 & Odenbach & 1 & & MittHVPfalz, 73, 1976, 28, no. 105 \\
\hline 23 & Bockenau & 1 & lj & Scheers 727 no. 131. \\
\hline 24 & Bad Kreuznach & 1 & ij & unpubl. \\
\hline 25 & Mainz & 3 & & FMRD, IV , 1157, 3-4 ; priv. \\
\hline 26 & Wiesbaden & 1 & & $F M R D, V, 1251,4$ \\
\hline 27 & Hofheim & 1 & & $F M R D, V, 1089,1$ \\
\hline 28 & Goldgrube & 23 & $2 \mathrm{la} ; 1 \mathrm{lc} ; 4 \mathrm{ld} ; 6 \mathrm{lj} ; 2 \mathrm{l}(\mathrm{j}$ ?) & FMRD, $V, 1145,8-30$ \\
\hline 29 & Bad Nauheim & 8 & 2 uncertain & FMRD $, V, 2096,2-8 ; 2100,1$ \\
\hline $29 a$ & Uffhofen & 1 & Id & FMRD, IV, 1041, 1 ; Polenz, 1982, no. 18 \\
\hline 30 & Alzey & 2 & & FMRD, IV, 1002, 4-5 \\
\hline 31 & Stetten & 1 & & MittHVPfalz, 70, 1972, 76 no. 166 \\
\hline 32 & Dannenfels & 2 & $1 \mathrm{lh} / \mathrm{j}$ & FMRD, IV, 2108, 2 ; MittHVPfalz, 70, 1972, 67, no. 144, 2. \\
\hline 33 & Eisenberg & 3 & $1 \mathrm{I}(\mathbf{j} ?)$ & FMRD, IV, $2111,7-9$ \\
\hline 34 & Bad Dürkheim & 4 & $1 \mathrm{lj} ; 1$ uncertain & FMRD, IV , 2233, 1 ; MittHVPfalz, 70, 1972,67 no. $141 ; 73,1976,27$, no. $96 ;$ Scheers 727 no.130b \\
\hline 35 & Frankenthal-Eppstein & 1 & & MittHVPfalz, 82, 1984, 54 \\
\hline 36 & Ruppertsberg & 1 & & $F M R D, I V, 2263,2$ \\
\hline 37 & Mutterstadt & 1 & lb & MittHVPfalz, 70, 1972, 73, no. 159, 2. \\
\hline 38 & Ludwigshafen-Rheingönheim & 2 & & FMRD, IV, $2215,1-2$ \\
\hline $38 a$ & Ladenburg & 2 & $1 \mathrm{lb}$ & Mannsperger, 1984 , p. 241 , note 5 \\
\hline 39 & Schifferstadt & 1 & & FMRD, IV, 2316, 1 \\
\hline 40 & Neustadt & 1 & $\mathrm{lb}$ & MittHVPfalz, 70, 1972, 74, no. 160 \\
\hline 41 & Gommersheim & 2 & & MittHVPfalz, 78, 1980, $27 ; 80,1982,312,71,1$ \\
\hline 42 & Pfalz & 6 & & FMRD, IV, 2330, 10-15 \\
\hline 43 & Waldfischbach & 1 & lj & MittHVPfalz, 68, 1970, 63, 181 \\
\hline 44 & Ruppertsweiler & 1 & $1 \mathrm{lj}$ & MittHVPfalz, 68, 1970, 62, no. 177 \\
\hline 45 & Wahlheim & 1 & $11(j$ ?) & FMRD, Il, $4368 \mathrm{E} 1,1$ \\
\hline 46 & Erkenbrechtsweiler & 1 & & $F M R D, 11,4373,2$ \\
\hline 47 & Breisach-Hochstetten & 4 & la & FMRD, II, 2072, 17-20 \\
\hline 48 & Hüfingen & 8 & $4 \mathrm{la}$ & FMRD $111,2031,1-2 ; 203214-15 ; 2032 \mathrm{E} 1,5-8$ \\
\hline 49 & Oflingen-Brennet & 2 & $\mathrm{ilb} ; 1 \mathrm{lj}$ & FMRD, II, 2233,1-2 \\
\hline 50 & Altenburg & 3 & $1 \mathrm{k}$ & Mannsperger, 1984, p. 238 \\
\hline
\end{tabular}

* uncertain $=$ identification as Scheers 186 uncertain. Otherwise the number of examples from Scheers' classes, where known, is given. 
Scheers 191 (Remi - see also Scheers 201) (fig. 48)

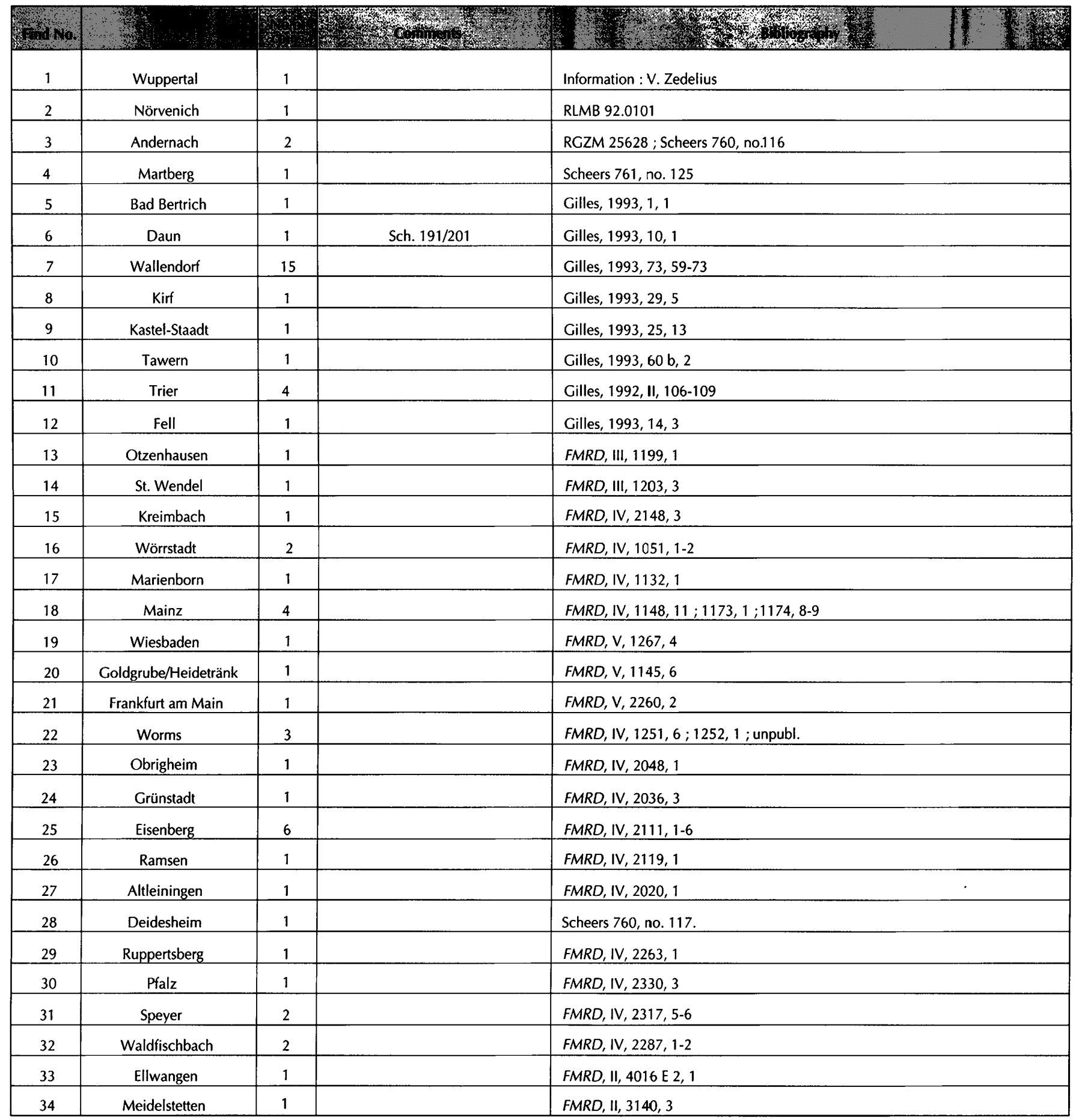


LT 5368/5401 (Sequani) (fig. 49)

\begin{tabular}{|c|c|c|c|c|}
\hline 1 & Ensch & 1 & & Gilles, $1993,13,1$ \\
\hline 2 & Kastel-Staadt & 1 & & Gilles, $1993,25,16$ \\
\hline 3 & Borg & 1 & & Gilles, 1993, 6, 7 \\
\hline 4 & Dünsberg & 5 & & Mus. Vor.- u. Frühgesch. Berlin \\
\hline 5 & Bad Nauheim & 1 & & $F M R D, V, 2096,9$ \\
\hline 6 & Goldgrube/Heidetränk & 3 & & $F M R D, V, 1145,3-5$ \\
\hline 7 & Frankfurt am Main & 2 & & FMRD $, \mathrm{V}, 2269,3 ; 2290,1$ \\
\hline 8 & Siefersheim & 1 & Castelin 765 ; cf. LT 5527 & FMRD, IV, 1037, 2 \\
\hline 9 & Dienheim & 1 & & unpubl. \\
\hline 10 & Pfalz & 2 & & $F M R D, I V, 2330,23-24$ \\
\hline 11 & Mannheim-Vogelstang & 1 & & $F M R D, \| 1,1130 / 1,1$ \\
\hline 12 & Lahr/Schwarzwald & 1 & & $F b B W, 12,725,4$ \\
\hline 13 & Sasbach & 1 & & FMRD, II, $2059 \mathrm{E} 2,1$ \\
\hline 14 & Breisach-Hochstetten & 17 & & FMRD, $11,2072,2-16 \& 21-22$ \\
\hline 15 & Oberrimsingen & 1 & & $F M R D, 11,2086 / 1,1$ \\
\hline 16 & Mengen & 1 & & $F M R D, 11,2083,1$ \\
\hline 17 & Istein & 1 & & $F M R D, 11,2153 \mathrm{a}, 1$ \\
\hline 18 & Herten & 3 & & $F M R D, \| 1,2153,1 ; 2153$ E $2,2-3$ \\
\hline 19 & Hüfingen & 22 & & FMRD $, 1,2031,3-5 ; 2032,1-13 \& 16 ; 2034,1 ; 2032 \mathrm{E} 1,3-4 ; 2035 \mathrm{E} 1,1-2$ \\
\hline 20 & Döggingen & 1 & & FMRD, II, 2021, 1 \\
\hline 21 & Tuttlingen & 1 & & FMRD, II, 3292, 1 \\
\hline 22 & Nendingen & 1 & & $F M R D, \| 1,3284,1$ \\
\hline 23 & Ebingen & 1 & & $F M R D, 11,3006,1$ \\
\hline 24 & Heimsheim & 1 & & FMRD, II, $4303 \mathrm{a}, 1$ \\
\hline 25 & Grossengstingen & 1 & & FMRD, II, 3168, 1 \\
\hline 26 & Grabenstetten & 1 & & FMRD, II, 3166, 6 \\
\hline 27 & Altenburg & 10 & 1 "DOCl" & Allen, 1978, 23-28, 36-37;Mannsperger, 1984, 238 \\
\hline 28 & Friedrichshafen & 2 & & $F M R D, 11,3271,1-2$ \\
\hline
\end{tabular}

\section{Scheers 194 (Remi) (fig. 50)}

\begin{tabular}{|c|c|c|c|}
\hline 1 & Münster & 1 & $F M R D, V I 4043,1$ \\
\hline 2 & Soest & 1 & $F M R D, V I 5072,1$ \\
\hline 3 & Vlatten & 1 & $B J b, 155 / 156,1955 / 1956,577$ \\
\hline 4 & Mainz & 1 & Scheers 767, no. 23 \\
\hline 5 & Trier & 1 & Gilles, 1992, II, 110 \\
\hline 6 & Ottweiler & 1 & FMRD, III, 1069, 1 \\
\hline
\end{tabular}


Scheers 195 (Remi) (fig. 50)

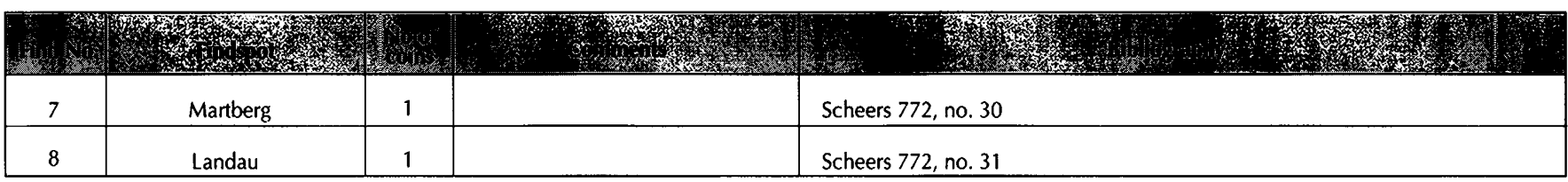

Scheers 197 (Suessiones) (fig. 50)

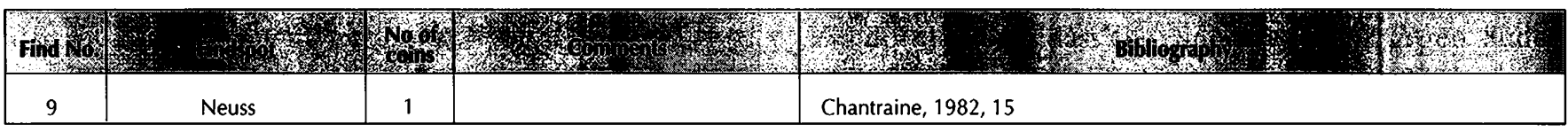

Scheers 198 (Suessiones) (fig. 50)

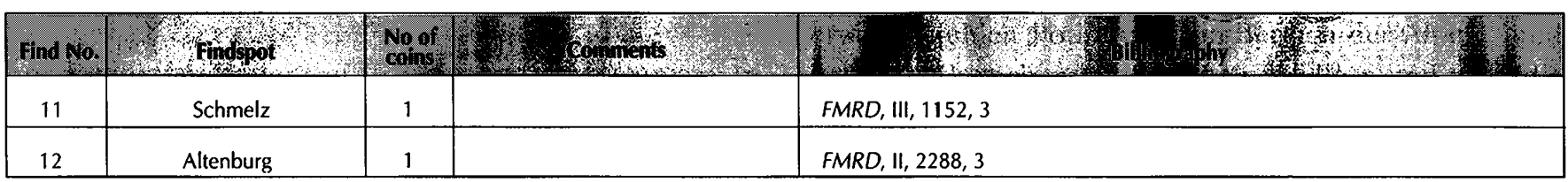

Scheers 190 (Nervii) (fig. 50)

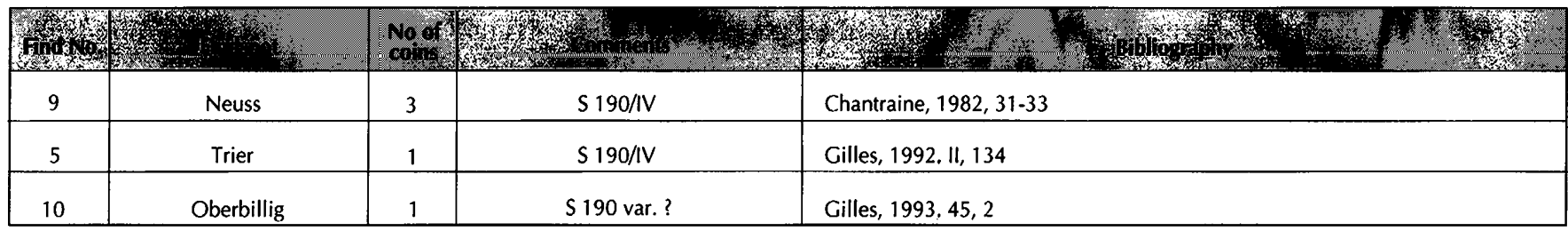

Senones (fig. 51)

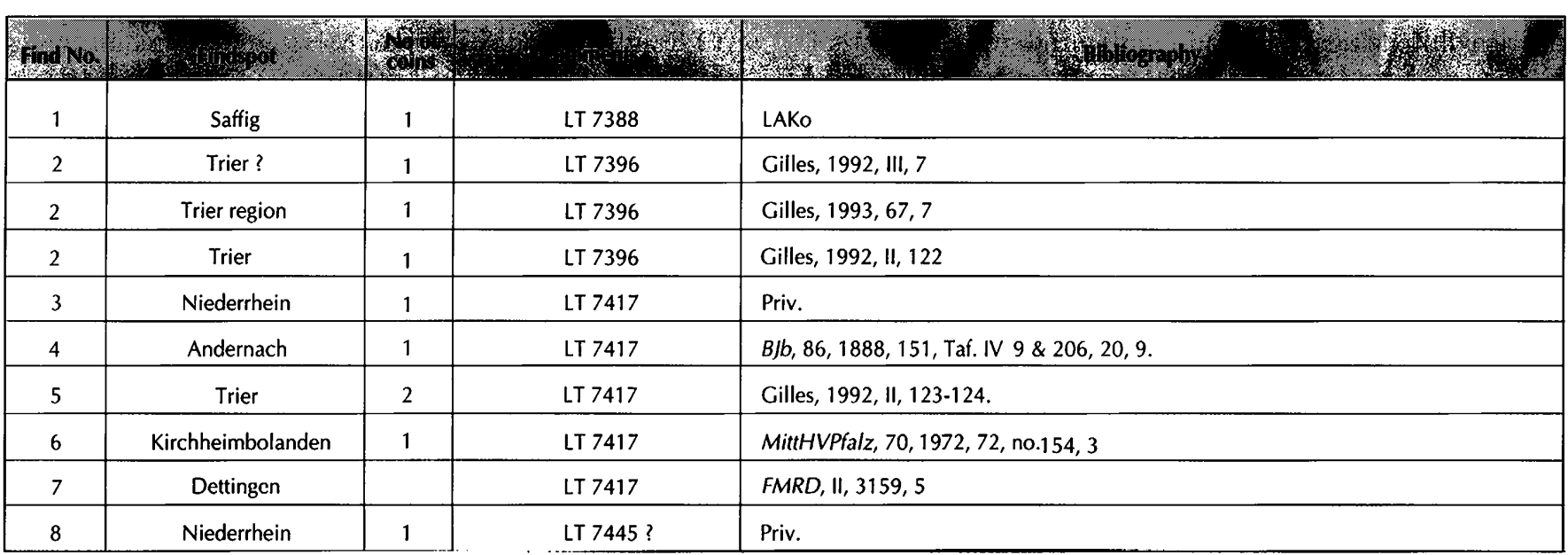


Aedui (fig. 52)

\begin{tabular}{|c|c|c|c|c|}
\hline 1 & Haltern & 1 & LT 5080 & FMRD, VI, 4057, 1607 \\
\hline 2 & Rothselberg & 1 & LT 2935 & MittHVPfalz, 72, 1974, 39, no.110 \\
\hline
\end{tabular}

Helvetii (fig. 52)

\begin{tabular}{|c|c|c|c|c|c|}
\hline fink: & 4 & $\begin{array}{l}\text { No of } \\
\text { coins }\end{array}$ & 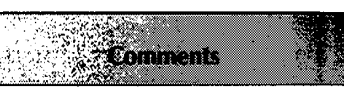 & 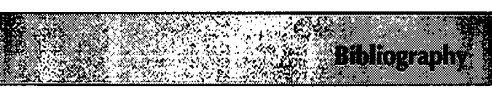 & Wxity \\
\hline 3 & Andernach & 1 & "Potinmünze der Nordhelvetii" & RLMB 38.637 & \\
\hline 4 & Hüfingen & 1 & LT 9361 & $F M R D, 11,2032,17$ & \\
\hline 5 & Altenburg & 4 & LT 9361 & Allen, $1978,29-30,38-39$ & \\
\hline
\end{tabular}

LT 7011 (incertaines de l'Est) (fig. 52)

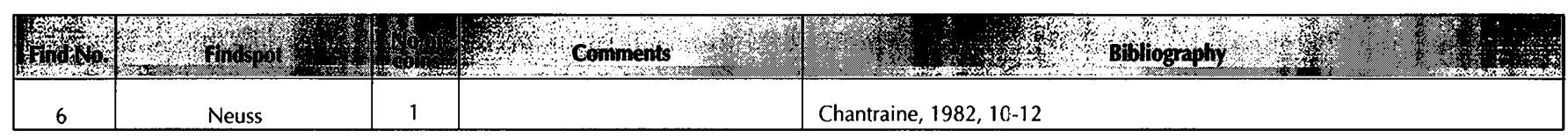

Lingones (fig. 52)

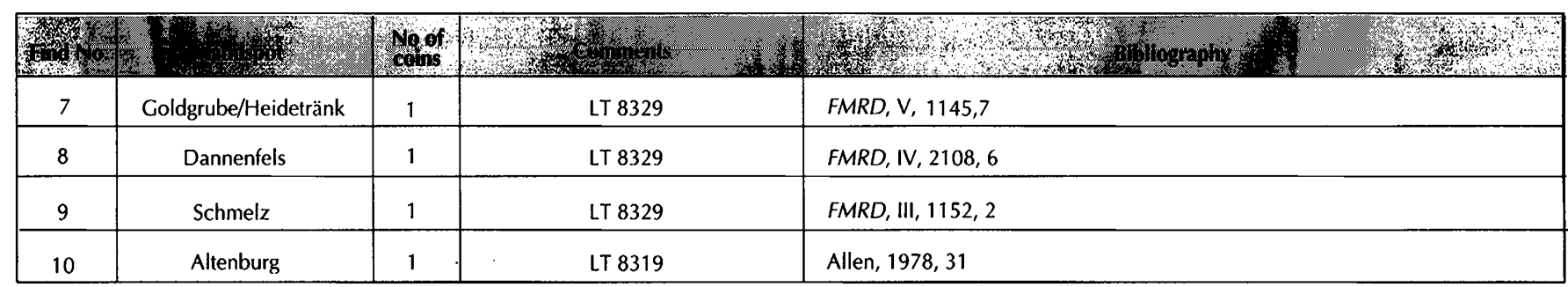




\section{Bibliography and abbreviations}

ALLEN D.F

1976, The Houssen Hoard at Colmar, RBN, 122, p. 79-85.

1978, The Coins from the Oppidum of Altenburg and the Bushel Series, Germania, 56, p. 190-229.

BJb : Bonner Jahrbücher.

BEHRENS G.

1949/50, Keltenmünzen im Rheingebiet, Prähistorische Zeitschrift, 34/35, p. 336-354.

BERNHARD H., LENZ-BERNHARD G.

1991, Das Oberrheingebiet zwischen Caesars gallischem Krieg und der flavischen Okkupation (58v. -73 n. Chr.). Eine siedlungsgeschichtliche Studie, MittHVPfalz, 89, p. 11-347.

BURKHARDT A.

1993, Produktionsreste keltischer Potinmünzen vom Kegelriss bei Ehrenstetten, Gemeinde Ehrenkirchen, Kreis BreisgauHochschwarzwald, Archäologische Ausgrabungen in BadenWürttemberg, 1992, Stuttgart, p. 116-120.

\section{ChANTRAINE H.}

1982, Novaesium VIII, Berlin (Limesforschungen, 20).

CORDIE-HACKENBERG R., HAFFNER A.

1991 : Das keltisch-römische Gräberfeld von Wederath-Belginum, 4.

FbBW : Fundberichte Baden-Württemberg.

FMRD, M.R.-ALFŌLDI (ed.)

1960ff. : Fundmünzen der römischen Zeit in Deutschland.

GiLles K.J.

1984, Keltische Fundmünzen aus Trier, in: Trier Augustusstadt der Treverer. Exhibition catalogue, Trier, p. 20-26.

1992, Neue Funde und Beobachtungen zu den Anfängen Triers, Trierer Zeitschrift, 55, p. 193-232.
1993, Keltische Fundmünzen im östlichen Treverergebiet, Trierer Zeitschrift, 56, p. 35-66.

GORECKI J.

1981, Münzen aus Asberg, Funde aus Asciburgium, 8.

LAKo : Landesamt für Denkmalpflege, Koblenz.

MANNSPERGER D.

1984, Keltische Münzen aus Baden-Württemberg - Neue Aspekte und Funde, in: G. Grasmann, W. Janssen, M. Brandt, Keltische Numismatik und Archäologie, p. 230-253 (BAR int. ser. 200).

MittHVPfalz: Mitteilungen des Historischen Vereins der Pfalz.

MZ: Mainzer Zeitschrift.

OESTERWIND B.

1989, Die Spätlatènezeit und die frühe rōmische Kaiserzeit im Neuwieder Becken, Bonner Hefte zur Vorgeschichte, 24.

RGZM : Römisch-Germanisches Zentralmuseum, Mainz.

RLMB : Rheinisches Landesmuseum, Bonn.

SCHEERS S.

1979, Le Tïtelberg et la circulation monétaire sur le territoire des Treveri, SFMA, 1, p. 225-239.

WFILI.FR R.

1984, Die Treverer-Münzprägung am Beispiel des Titelberges, in: Trier Augustusstadt der Treverer. Exhibition catalogue, Trier, p. 100-105.

\section{ZEDELIUS V.}

1984, Keltische Fundmünzen vom Martberg, in: Trier Augustusstadt der Treverer. Exhibition catalogue, Trier, p. 112-115. 